\title{
Learning to Make Discipline-Specific Knowledge Through Writing
}

\section{Appronfondir des connaissances spécifiques à chaque discipline par l'écriture}

\author{
Philippa Spoel and Renée Corbeil \\ Laurentian University
}

During the past decade, the writing across the curriculum (WAC) movement increasingly has turned to the theoretical and pedagogical approaches of writing in the disciplines (WID), thanks to a rapidly growing body of research on the fieldspecific practices of textual knowledge making ${ }^{1}$ in academic and professional writing (e.g., Berkenkotter and Huckin; Geisler; Freedman; Macdonald). As Robert Jones and Joseph Comprone explain, the "second stage" of WAC scholarship goes beyond the premise that writing is an important mode of learning across the curriculum to examine "the relationship between writing and ways of thinking and knowing in disciplinary communities" (p.61). Through the analysis which follows, we hope to contribute to this study of the relationship between writing and discipline-specific kinds of learning and knowledge making. Specifically, we will draw on sample writing to learn activities from four writing-intensive courses at our university ${ }^{2}$ to show how the design of these pedagogical genres incorporates the learning of professional disciplinary modes of thinking and communicating. Based on the analysis of these activities, we suggest that, although pedagogical genres such as these are not identical to professional genres, they do possess features that may help undergraduate students to learn about and begin to enter professional communities of discourse.

The activities we have selected for discussion were presented by our colleagues at faculty workshops on writing to learn activities held in the fall of 1997. As faculty consultants for our university's WAC program, we organized the workshops as forums for interdisciplinary exchange on the possibilities for writing to learn in different programs of study. Faculty participated voluntarily and we did not vet or otherwise screen the activities presented; rather, we encouraged faculty to interpret 
Atelier:

-présentations

d'activités pédagogiques pour mettre en pratique le principe "écrire pour apprendre"

-quatre activités seront discutées:

"Learning Journal", Nursing

"Exercise on Using an Academic Literature", Economics

"Exercice de compréhension de texte", philosophie

"Prise de notes", sociolinguistique the concept of "writing to learn activity" in the way that made most sense to them. In all, five activities were presented at the English workshop (from Economics, English, Nursing, Modern Languages and Religious Studies), and three at the French workshop (two from philosophie and one from sociolinguistique); in the interests of providing examples from several disciplines and representing different pedagogical approaches, we have selected the following four: ${ }^{3}$

- "Learning Journal", Nursing

- "Exercise on Using an Academic Literature",Economics

- "Exercice de compréhension de texte", philosophie

- "Prise de notes", sociolinguistique

Our purpose in discussing these activities is not first and foremost to recommend them as models to other teachers, though some readers may well find them valuable; instead, our objective is to try to understand the design of these activities through the theoretical framework of WAC and WID, and in particular the concepts of pedagogical and professional genres. We also should note that this study focuses on the teachers' designs not the students' practices of the activities - that is, on what the activities are intended to accomplish rather than on what they in practice do accomplish. We are, of course, very interested in the latter issue as well, but it is beyond the scope of this study.

Before embarking on further discussion of the activities themselves, the next section summarizes our theoretical framework: first, we briefly review relevant aspects of the principles of writing to learn and writing as discipline-specific, and then we suggest a conceptual representation of the relationship between pedagogical and professional genres which we will employ in our discussion of each of the four activities. 
Perspective cognitive

-l'écriture est un processus complexe lié à la pensée

-l'écriture favorise la croissance intellectuelle

-l'écriture informelle qui aide à trouver des idées

\section{Perspective}

"expressisvist"

-l'écriture développe les connaissances individuelles

-l'écriture est un outil pour la découverte de soi et le développement d'une voie personnelle et unique

\section{Writing to Learn}

Since the landmark research of scholars such as James Britton, Janet Emig, James Moffett and Donald Murray, among others, the principle of writing as mode of learning has fundamentally informed composition teaching and, subsequently, the development of WAC programmes. Typically, the conception of writing as mode of learning foregrounds the process of meaning-making rather than the preparation of final products. As such, it privileges informal and exploratory writing as vitally important to the discovery and development of ideas and meaning. Within this general understanding, two main theoretical perspectives can be distinguished for interpreting writing as a mode of learning. ${ }^{4}$

1.The cognitive perspective stresses writing as a complex mode of thinking. ${ }^{5}$ In this sense, writing is a means of individual intellectual development, a way of formulating ideas and learning subjectmatters. This view presupposes that writing, and particularly informal writing, helps students to think and learn in courses across the curriculum, from the humanities to the social sciences and natural sciences. As Paul Connolly explains in Writing to Learn Mathematics and Sciences, "Writing to Learn' is less about formal uses of writing to display memory and test mastery than it is about informal writing; about language that is forming meaning; about writing that is done regularly in and out of class to help students acquire a personal ownership of ideas conveyed in lectures and textbooks" (p.3).

2. While Connolly notes the role of writing to learn as a means for students to achieve "personal ownership" of course content, the expressivist perspective of writing to learn places even greater 
Perspective LIP

\section{Knoblauch et} Brannon:

-l'écriture est une connaissance heuristique valable pour aider les étudiants à apprendre la matière intégrée dans tous les programmes (perspective cognitive)

-l'écriture est un moyen de développer les connaissances personnelles (perspective "expressivist")

-écrire pour apprendre" s'oppose à l'apprentissage de la forme emphasis on the "personal" dimensions of writing. ${ }^{6}$ Informal writing in this view creates opportunities for students to explore, develop and express their individual selves. Writing is validated primarily as a mode of self-discovery and self-expression. As Ann Johns explains, "In a class based on Expressivist theory, the emphasis is on self-discovery and development of a unique, personal voice.... [In] approaches that draw from Expressivism, the effort is made to liberate students from outside constraints so that they can write and read freely and creatively" (p.10). ${ }^{7}$

Although these two perspectives emphasize different aspects of the concept of writing to learn, they also share common ground and both seem to have influenced the development of what Jones and Comprone might call "first stage" WAC programs. Indeed, C. H. Knoblauch and Lil Brannon's mid-1980s argument for writing across the curriculum draws on both these perspectives to show the significance of informal, exploratory writing activities in courses across the curriculum as opposed to a "grammar across the curriculum" approach to WAC. According to them, writing across the curriculum programs at the college or university level should use writing as means for "making connections" and for "personal meaning making" (p.468). This process is primarily an "expressive" one because it allows individual students "to confront new experience, make connections with other experience and discover some personal coherence" (p.470); it gives them the "freedom to explore the ideas of a discipline from a personal vantage point... without the anxiety of formal expectations that are made to seem even more important than the search for meaning" (p.470). In Knoblauch and Brannon's argument, then, writing to learn within WAC programs can help students learn about and make connections with disciplinary subjectmatters. They present this as an alternative to writing instruction motivated by "a concern for formal constraints" 


\section{L'écriture spécifique à} la discipline

- l'écriture est un outil pour lier la pensée et les connaissances acquises qui sont spécifiques à la discipline, incluant les formes de pensée

-principe social

- communautés qui partagent une forme particulière de communication

- modèles spécifiques de recherche et de communication which places undue stress on the "superficial decorum" of "technical propriety" (pp.469 to 470).

\section{Writing as Discipline-Specific}

If the "first stage" of waC theory and practice has made a compelling case for integrating writing as a mode of learning across the curriculum, in the senses discussed above, then the next stage, as Jones and Comprone argue, should attend more to "the relationship between writing and ways of thinking and knowing in disciplinary communities" (p.1). In this approach, the principle of writing as discipline-specific becomes central. By contrast with the emphasis in writing to learn theory on writing as an individual cognitive and personal process, theories of writing as discipline specific stress what Johns calls the "socioliterate" nature of writing (p.14). The concept of discourse communities or, as James Reither calls them, "knowledge/discourse communities" (p.143) is central to this social view of writing: each discipline shares particular methods of inquiry and ways of communicating that identify it as a distinctive discourse community. Thus, the kinds of learning and cognitive activities that writing facilitates vary from discipline to discipline and course to course.

But does the shift of focus that Jones and Comprone call for entail a rejection of the original principle of writing to learn? Does attending to the disciplinary conventions of writing and communication mean re-emphasizing a narrow "concern for formal constraints" and "technical propriety"? Does a "philosophical and tactical divide" exist between these principles, a conflict characterized by Harriet Malinowitz as "voice versus discourse, learning versus performance, process versus form" (p.292)?

Our own view is that the concepts of writing as a mode of learning and of writing as a discipline-specific practice do not necessarily conflict with each other; rather, we see the growth in studies of disciplinary practices of communication as providing the basis for an enriched and 
-apprendre ne se limite pas seulement au contenu du cours ou aux connaissances personnelles, mais aussi à la forme de la discipline.

\section{Connaissances des professionnels et apprentissage des débutants}

- les professionnels ont les connaissances spécifiques aux formes

- cette connaissance cognitive est liée aux activités de la discipline reconfigured understanding of writing as a mode of learning, one which transcends "the repressive false dichotomy between form and process" (Coe, p.181). That is, we suggest that the range of "learning" that occurs through writing includes not only learning course content or engaging in self-discovery, but also - and perhaps most importantly? - learning the forms of inquiry and textual knowledge-making that characterize particular disciplines and that vary from discipline to discipline.

\section{Pedagogical and Professional Genres}

Recent developments in genre theory, particularly in the context of scholarship on writing in the disciplines, offer a fruitful avenue to further conceptualize the relationship between the principles of writing to learn and writing as discipline-specific. Genre theory allows us to understand the community-based practices of academic discourse not simply as a superficial set of formal constraints arbitrarily imposed on texts, but instead as ways of thinking and making meaning that are "created by and for the collective or group" (Paré and Smart, p.146). As genres are activated in disciplinary communities, they construct as well as communicate discipline-specific knowledge (see Paré and Smart, p.146; Berkenkotter and Huckin, p.1 and 23) As Carol Berkenkotter and Thomas Huckin explain, genres address and respond to specific rhetorical situations within particular communities of discourse by drawing on cognitive strategies that are socially derived (see Berkenkotter and Huckin, p.7 to 13). In this sense, writing within a particular genre means at once using writing to think - to engage in complex acts of cognition - and to communicate using forms that other members of the community will recognize and understand. Importantly, this theory stresses that the kinds of thinking and knowledge-making that a particular genre fosters are specific to the academic discipline or "knowledge/discourse community" in which the genre occurs. In this sense, the principle of writing as mode of 
-comment les débutants en écrivant apprennentils les connaissances spécifiques aux formes de la discipline? learning and thinking certainly applies, but it is refined to acknowledge the different disciplinary forms of cognition and meaning-making.

While scholars such as Berkenkotter and Huckin concentrate primarily on the communicative activities of professional or expert members of disciplinary communities, we are concerned with the role that undergraduate writing to learn activities play in the enculturation of undergraduate university students into the genres of thinking and communicating that characterize particular disciplines. That is, how do novices write to learn discipline-specific forms of knowing and communicating? Such a focus seems to us especially important given Cheryl Geisler's finding that the North American undergraduate curriculum is designed to maintain a distinction between novice and expert by making "domain content" (i.e., the subject-matter of a discipline) what undergraduate students learn without making the learning of a discipline's "rhetorical process" (i.e., its forms and strategies of textual knowledge making) part of the curriculum. Do the writing to learn activities that our colleagues have designed reinforce this distinction or do they, at least to some extent, suggest the possibility of learning "rhetorical process" as well as "domain content"? As students write to learn a subject-matter, can they simultaneously begin to learn how to think and communicate like professionals?

To answer this question with respect to the activities our colleagues have designed, we need to distinguish between expert genres (such as scholarly articles, conference presentations, published book reviews, etc.) and curriculum or pedagogical genres (such as book reviews, essays, lab reports, exams, etc.). According to Berkenkotter and Huckin, "many of these pedagogical genres contain some of the textual features and some of the conventions of disciplinary genres but...they are also linked to and instantiate classroom-based activities such 
Formes pédagogiques:

-sont entreprises par les étudiants et les étudiantes dans un contexte scolaire

- sont différentes des formes professionnelles

-se sont des activités "écrire pourapprendre" à notre université

-aident les étudiants et les étudiantes à développer des connaissances professionnelles spécifiques aux disciplines as reading, writing, solving decontextualized math problems or conducting simple experiments of the kind found in lab manuals" (p.13). Each of the four activities that we discuss below clearly functions as a pedagogical genre in the sense that each addresses the rhetorical context of the classroom community, rather than the context of professional scholarship. However, as we hope to show, each of these pedagogical genres also implies the learning of at least some dimensions of professional practice and textual knowledge making. That is, these writing to learn activities are designed to begin to enculturate students into discipline-specific genres of knowing and communicating, genres that approximate professional discourse. Figure 1 represents our perception of the basic relationship between these pedagogical genres and the learning of professional genres of thinking and communicating. We will flesh out this basic representation with specific details as we discuss each activity in turn:

\begin{tabular}{|l|}
\hline Pedagogical Genre \\
Novice Writers \\
-writing to learn activties \\
Forme pédagogique \\
Écriture par les \\
débutants \\
-activités "écrire pour \\
apprendre"
\end{tabular}

\begin{tabular}{|c|l|}
\begin{tabular}{c|c|} 
Direction of \\
Learning
\end{tabular} & $\begin{array}{l}\text { Expert / Professional } \\
\text { Genre } \\
\text { Expert Writers } \\
\text { l'apprention de } \\
\text { •discipline-specific } \\
\text { thinking and } \\
\text { communicating }\end{array}$ \\
$\Rightarrow$ & $\begin{array}{l}\text { Forme professionelle } \\
\text { Écriture par les } \\
\text { professionnels } \\
\text { opensée et } \\
\text { communication } \\
\text { spécifique à la discipline }\end{array}$ \\
\hline
\end{tabular}

Figure 1

Drawing on this conceptualization of the relationship between pedagogical and professional genres, we turn now to the activities themselves. We will describe each in turn fairly briefly, drawing on the professors' own explanations of their intentions as well as our own perceptions of each 
design, and then close with a discussion that considers them more fully in relation to each other and to issues in WAC and genre theory.

\section{Writing to Learn Activity 1: Learning Journal, Nursing}

The first activity has been designed by Rick Vanderlee, a professor in Nursing who also is pursuing doctoral studies in education. Rick uses a learning journal in his first-year "Professional Growth" course as part of a carefully designed sequence of writing activities (see Appendix $A$ for an explanation of this sequence). According to Rick, the purpose of the journal is 1 . to give each student insight into her or his own "emotional and cognitive rhythms as a learner and professional"; 2. to help students to think critically about the world they live in; 3 . to allow Rick to read some sections of their journals (at their choice) so that he can learn about himself as a teacher (see Appendix $A$ for the full text of Rick's journal explanation).

In many ways, the design of Rick's learning journal epitomizes the traditional view of writing to learn as an informal, exploratory kind of writing that gives students the freedom to express themselves in unique, personal ways while simultaneously learning about a subject-matter. For Rick, this is not only the subject-matter of the Nursing curriculum but also, reflecting his own doctoral studies in education, the subject-matter of learning itself; that is, he asks students to reflect on their own learning styles. Although Rick provides general questions to prompt student writing, he explains that he wants the journal to be a place in which students can write in ways that suit their individual learning styles; he does not impose a particular form but instead encourages diversity of expression, welcoming narrative, poetic and multimedia approaches, for example, as well as more standard academic discourse. In this sense, we see the learning journal as a pedagogical genre intended to help students become "whole" people and, in the words of our university's stated mandate, "life long learners": the journal encourages personal development, intellectual and emotional growth, individual expression and self-knowledge. It is designed to help students, as Rick puts it, "find meaning" for themselves, not just within the course but in the longer term as well.

However, while promoting this personal development, the journal also fosters learning particular to the professional field of Nursing. Reflecting critically on their emotional and cognitive rhythms and on the world around them is a way for students to begin to practice the kinds of knowledge making that will help them to become better health care professionals. More concretely, it helps them to practice the kinds of writing now required in our province for health care professionals. As of 1998 , legislation is in effect that requires all health care professionals to submit an annual dossier on their professional practices. According to Rick, on the one 
hand, this dossier is intended to motivate deeper reflective practices among health care professionals; on the other hand, it serves as a quality assurance measure. Thus, the learning journal gives students an opportunity to learn - through practice - some aspects of genre knowledge that they will need to use strategically as health care professionals while at the same encouraging the overlapping goal of personal growth and expression (see figure 2).

\begin{tabular}{|l|}
\hline Pedagogical Genre \\
-learning journal \\
-informal and exploratory \\
-appeals to different \\
learning styles by allowing \\
diversity of form and \\
content \\
-learning about nursing and \\
learning about learning \\
-assigned and evaluated by \\
teacher in classroom \\
context
\end{tabular}

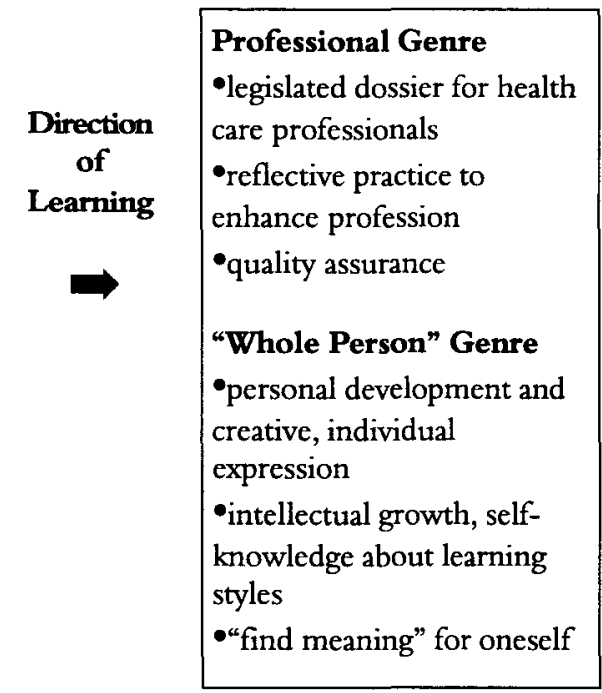

Figure 2

\section{Writing to Learn Activity 2: Exercise on Using an Academic Literature, Economics}

The writing to learn activity presented by David Robinson, professor in Economics, at the 1997 WAC faculty workshop focuses less than Rick's on informal, individual expression and personal discovery and more on an explicit, structured learning about expert academic forms of communication. Entitled "Training first and second year students to use an academic literature", Dave has designed this activity as a way for students to investigate and familiarize themselves with the academic literature of Economics particular to his second-year course on "Strategic Thinking: Game Theory for Business and Social Science" (see Appendix B for his assignment description).

As a pedagogical genre, this activity provides students with precise and detailed guidelines for following a structured sequence of steps. These steps have a dual 
purpose: to help students learn about — that is, to recognize and identify — features of expert discourse in Economics, in particular the scholarly article genre, and, to a limited extent, to teach students how to enact aspects of expert genre knowledge, such as how to research and read a scholarly article and how to write an abstract. As Dave explains, one of the initial objectives of this sequenced assignment is to get students to locate scholarly periodicals and articles from the disciplinary sub-field of game theory in the library and to introduce them to citation practices in that field. These initial activities in turn provide the basis for students to identify specific aspects (such as problem-definition, justification of study, kinds of data, methodology and conclusion) of each article's content and rhetorical process, thereby further introducing them to disciplinary genre knowledge. The assignment also is intended to teach students how to perform some aspects of composing a scholarly article, such as writing an abstract, preparing tables and diagrams, providing references and composing an acknowledgment. Admittedly, this practice is far from the "real thing", given that first and second year students do not have the "domain content" or background knowledge to compose scholarship nor are they familiar with the scholarly contexts and audiences that professionals in the field respond to and address. The motivating and responding context for their texts remains the classroom with the teacher as reader and evaluator. However, while acknowledging the exigencies and expectations of the classroom as primary rhetorical situation for this assignment, we nonetheless find that the design of Dave's activity demonstrates an ingenious method for, at the very least, beginning to acculturate students into both the rhetorical process and the domain content of scholarship in game theory within the discipline of economics (see figure 3 ).

\section{Activité "écrire pour apprendre" 3: Exercice de}

\begin{tabular}{|l|}
\hline Pedagogical Genre \\
•exercise to train students to \\
use an academic literature \\
-structured sequence of steps \\
and explicit guidelines \\
-assigned and evaluated by \\
teacher in classroom context \\
\hline
\end{tabular}

Figure 3

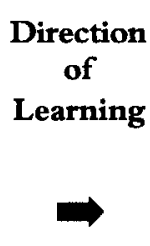

\begin{tabular}{|l|}
\hline Professional Genre \\
•research in economics \\
periodicals using citations \\
-read scholarly articles \\
-identify aspects of genre \\
knowledge (e.g., problem- \\
defnition, justification for \\
study, data, methodologies, \\
conclusions) \\
•practice aspects of genre \\
knowledge (e.g., abstract, \\
diagrams \& tables, \\
references, \\
acknowledgements) \\
\hline
\end{tabular}




\section{compréhension de texte, philosophie}

Lucien Pelletier, professeur de philosophie, utilise un exercice pour familiariser les étudiants à une lecture approfondie d'un texte philosophique. L'exercice est bien calibré pour un cours de niveau de première année: le texte est bien choisi, les questions sont claires et bien ficelées, et il y a une progression dans la complexité des questions. Pour un étudiant de première année qui est initié à la pensée philosophique pour la première fois, la tâche d'analyser peut être ardue et complexe. Cette progression permet à l'étudiant dans un premier temps d'acquérir un nouveau savoir et dans un deuxième temps de se préparer à une activité d'analyse (voir Appendice C).

Un des objectifs de l'exercice est d'amener l'étudiant à réfléchir sur le contenu du texte avec un oeil plus critique et analytique. L'exercice, que Lucien présente, se compose de questions de compréhension. Dans une première partie, l'objectif est d'initier l'étudiant à saisir le contenu du texte. En posant des questions précises à chaque paragraphe, Lucien amène l'étudiant à développer une stratégie qui pourrait être utilisée pour n'importe quel texte soit en philosophie ou soit dans un autre domaine; l'étudiant apprend à déchiffrer le texte. Cette approche aide l'étudiant à développer une stratégie d'apprentissage afin d'entreprendre une lecture active et efficace d'un texte. (Lecavalier et Brassard). Les questions dirigent la lecture en fonction de la compréhension du texte. Les premières questions $(a, b, c, d, e)$, reflètent le concept de la tradition cognitive qui utilise l'écriture comme un moyen complexe pour développer la pensée. À la question a), Lucien demande au lecteur de trouver des renseignements précis (Quels sont les types de bonheur). À la deuxième question, il demande des renseignements précis tout en introduisant un analyse. Il encourage le lecteur à revoir ou consolider ce qu'il vient tout juste d'apprendre. Les questions c) et d) explorent l'analyse. Lucien permet à l'étudiant d'avoir des pistes afin de commencer à faire l'analyse de ce qu'il lit. La question e) sert de tremplin à la réflexion afin d'explorer de nouvelles idées. Contrairement aux questions précédentes, la réponse ne se trouve pas dans le texte. Létudiant doit comprendre les réponses aux premières questions afin de répondre à cette dernière. Les questions ( $\mathrm{f}, \mathrm{g}, \mathrm{h}$ ) ciblent davantage une réflexion plus approfondie du sujet étudié. Elles deviennent une activité qui élabore de nouvelles idées et de nouvelles expériences et qui communique les connaissances spécifiques à la discipline. La forme est déterminée par le contexte. Ces questions initient l'étudiant de façon plus rigoureuse à la pensée philosophique. L'exercice encourage l'étudiant à penser et à communiquer comme un professionnel (voir figure 4). 


\begin{tabular}{|c|c|c|}
\hline $\begin{array}{l}\text { Forme } \\
\text { pédagogique } \\
\text { •exercice de } \\
\text { compréhension d'un } \\
\text { texte philosophique } \\
\text { 'questions dirigées } \\
\text { •donné et évalué } \\
\text { dans le contexte de la } \\
\text { salle de classe }\end{array}$ & $\begin{array}{c}\text { Direction de } \\
\text { l'apprentissage }\end{array}$ & $\begin{array}{l}\text { Forme } \\
\text { professionelle } \\
\text { •lecture attentive } \\
\text { •étude des concepts } \\
\text { (définitions) } \\
\text { - développement de la } \\
\text { pensée philosophique } \\
\text { par des questions qui } \\
\text { amènent l'étudiant à } \\
\text { la réflexion au-delà } \\
\text { du texte }\end{array}$ \\
\hline
\end{tabular}

Figure 4

\section{Activité "écrire pour apprendre" 4: Prise de notes, français}

L'exercice, que je présente, a été élaboré pour les étudiants qui suivent leur premier cours de sociolinguistique. Cet exercice tente d'amener les étudiants à intégrer la matière présentée et à développer des stratégies pour la prise de notes afin d'intégrer des habitudes pour l'analyse et la synthèse (voir Appendice C). Cet exercice veut initier l'étudiant à développer une perspective disciplinaire afin de mieux analyser les données pour pouvoir émettre des opinions tout comme un professionnel le ferait dans la discipline. L'étudiant apprendra que la sociolinguistique utilise des méthodes de recherche qui l'identifie et qui permet d'élaborer de nouvelles idées. L'écriture peut contribuer à différentes formes et que son utilisation peut s'adapter aux possibilités et aux besoins de la discipline et du professeur.

Cette activité offre une forme pédagogique qui incite l'étudiant à développer une méthode de travail. Dans un premier temps l'étudiant doit lire un article soumis par le présentateur et doit répondre par écrit aux questions de compréhension. L'objectif d'une lecture active du texte est d'avoir certaines connaissances du sujet lors de la présentation. Il acquière un nouveau savoir pour se préparer à l'activité demandée. Par la suite l'étudiant doit faire une synthèse de la présentation, de la lecture de l'article et de la discussion en classe. Cette activité l'encourage à réfléchir sur le sujet et à développer des connaissances spécifiques aux formes de la discipline. 
L'étudiant développe des critères pour évaluer la situation sociolinguistique dans le pays choisi tout en développant des stratégies d'analyse et de synthèse qui suscitent une réflexion plus poussée. Cette activité initie l'étudiant à comprendre comment on écrit et on pense dans la discipline et à trouver des arguments qui sont soulevés dans un tel contexte. J'ai tenté de montrer que la tâche ne se limite pas seulement à trouver des faits et à les présenter mais à développer des arguments afin de présenter son analyse.

\begin{tabular}{|l|}
\hline Forme pédagogique \\
•prise de note \\
-résumé des notes \\
-réflextion élaborée et \\
dirigée (individuelle et \\
en groupe) \\
•donné et évalué dans \\
le contexte de la salle de \\
classe
\end{tabular}

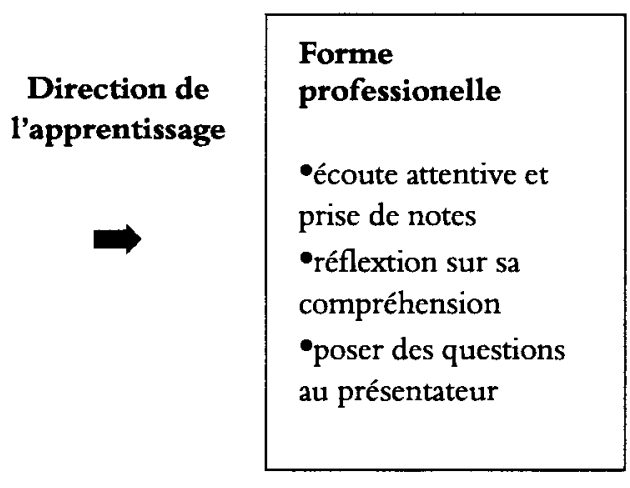

Figure 5

\section{Discussion}

The writing to learn activities we have just described demonstrate some of the diverse ways in which writing across the curriculum can implement both the principle of writing as a mode of learning in all disciplines and the principle of writing as specific to the ways of thinking and communicating within particular disciplines. As pedagogical genres, the writing to learn activities that our colleagues have designed clearly can play an important role in students' learning of a disciplinary subject-matter; more importantly, however, these genres can contribute, we maintain, to students' enculturation into the "rhetorical process" of a professional discourse community. We do not wish to overstate the extent of this latter learning, since necessarily enculturation is a gradual process which, as Berkenkotter and Huckin suggest, normally does not occur in a substantial way until graduate studies(p.118). But we are intrigued to discover that several teachers at our university are designing activities for undergraduate courses that seem to encourage learning 
the procedural knowledge of how to think and write in a discipline, and not only the declarative knowledge of the "facts" or content to be mastered in a course (Geisler, p.81, Walvoord and Sherman, p.59).

The kinds of activities that our colleagues identified as "writing to learn" suggests to us some of the forms of inquiry and modes of discourse validated by each of their disciplines. From our perspective as academics associated with the field of rhetoric and composition, Rick's learning journal most closely represents our expectations for the design of a writing to learn activity, primarily because it encourages exploratory writing and self-reflection. We also note, however, the relevance of this kind of writing to the development of a caring as well as knowledgeable nurse. Although we might be tempted to say that students from a range of disciplines could benefit from keeping this type of journal, the "professional growth" objectives motivating this assignment derive specifically from Rick's perception of the kinds of nurses he wants his students to become: nurses who have the emotional self-awareness and coping strategies to understand "what warning signals indicate that you are hitting an emotional low, and what factors tend to keep you going through the 'quitting times' of low morale, depression and loss of confidence"; nurses who are capable of "raising questions, explicating new thinking and transforming your personal understanding of the world"; nurses who think carefully about "how justly, ethically and caringly we perform our actions" (Appendix $A$ ). Notably, Rick asks his students to engage in emotional and ethical not just intellectual - learning, learning which could be seen as exceeding the traditional boundaries of academic training and inquiry but which, Rick suggests, is central to his students' professional formation.

Dave's Economics assignment seems by contrast to embody a more traditional sense of academic disciplinarity, focusing as it does on the "academic literature" of a field (rather than, as in Rick's case, on self-reflection and self-development). Interestingly, Dave sees his assignment as appropriate for virtually any university discipline, arguing that "University graduates should be able to retrieve information from the academic literature [of any given field]. They should be able to follow a debate through the literature, summarize it clearly and provide adequate references" (Appendix B). In its structure, then, Dave sees this activity as potentially valuable in many disciplines. We wonder though whether some fields of study might find the structure and objectives of this activity less meaningful to the development of disciplinary genre knowledge than others. Is it most appropriate for learning in the social sciences, rather than, for example, the humanities or natural sciences or engineering? Would Nursing students benefit from undertaking such an activity, perhaps in conjunction with or subsequent to the kind of learning journal that 
Rick assigns? We do not have answers to these questions but we raise them as issues. Certainly, Susan Peck Macdonald's study of differences in problem-definition in different areas of academic study suggests that initiating students into an "academic literature" may require not only a shift in the content but also perhaps the form of the pedagogical genre presented by Dave.

Had Dave not independently proposed his assignment as a "writing to learn activity", we confess that we might not have perceived it as such. This causes us to ask, how does one define "writing to learn"? Does writing to learn necessarily mean informal, exploratory, expressive writing or can it include more formalized and structured pedagogical activities? Within the tradition of composition studies exemplified by Knoblauch and Brannon's approach to WAC, the former understanding of writing to learn dominates and, in our own consultation with faculty, it is the one we tend to recommend. Yet we also recognize that the concept of "writing freely" mystifies the disciplinary and institutional exigencies which shape student writing and which students are quite aware of no matter how "free" we encourage them to be in their expression. Further, as Walvoord and Sherman note in the context of a Business course, students who adopted "freewriting" techniques for working on assignments received lower grades than students who "used more structured forms of pre-draft writing"(p.91). They compare "the mixed results of teaching freewriting with the more uniformly positive results of teaching 'inquiry strategies' - that is, more focused exercises designed to guide students through a specific type of inquiry process"(p.91). In this sense, we could say that Dave's exercise as much as Rick's journal is designed to lead students through a type of inquiry process specific to each of their disciplines. Both, then, are activities whose goals are to foster student learning, but the nature of the learning aimed at varies and hence the forms of discourse that students are asked to compose varies as well.

On peut interpréter l'exercice de compréhension de Lucien comme une activité à être exploitée dans différentes disciplines. La recherche de renseignements précis pour se préparer à une autre activité plus complexe peut sans aucune doute être reprise dans un autre domaine. Par contre les dernières questions que Lucien pose à l'étudiant encouragent ce dernier à explorer surtout sa pensée philosophique. La croissance de la complexité des questions introduit le lecteur à une pensée plus abstraite. L'étudiant est amener à se questionner et à analyser le texte pour ensuite l'interpréter comme un philosophe.

L'exercice en sociolinguistique amène aussi l'étudiant à aller chercher des renseignements précis. Létudiant développe des habiletés à lire et à prendre des notes afin de pouvoir analyser toutes les ressources pour en dernier présenter son 
opinion. Ces activités peuvent être utilisées dans un autre domaine. Toutefois lors de la lecture et de la recherche, je demande aux étudiants de travailler la synthèse tout en examinant la forme de l'argumentation. L'activité, qui amène l'étudiant à développer une méthode de travail, a été développée afin d'insister sur le contenu et aussi la forme pour à la fin analyser la tâche comme un sociolinguiste le ferait.

The designs of our colleagues' activities also can be understood in terms of the ongoing debate among genre researchers and theorists about the extent to which it is possible or desirable to provide explicit instruction to students in disciplinebased genres of communication (for a $\mathbf{n}$ overview of this debate, see Berkenkotter and Huckin, pp.151 to 163; see also Freedman "Learning"; Freedman and Medway Genre, 1994, Freedman and Medway Teaching, 1994 and Christie, 1987). For the most part, we would say that these writing to learn activities introduce students to discipline-based genres in an implicit, non-formulaic manner rather than through explicit, rule-based, decontextualized instruction. That is, as Aviva Freedman suggests, these activities seem to presume that students will learn how to communicate in disciplinarily appropriate ways by actually doing or performing the genres that characterize a field of study, rather than by consciously imitating models or applying sets of rules ("Learning", p.111). For example, Rick explains at some length the cognitive and emotional objectives of the learning journal and he provides explicit questions to prompt student writing - in this sense, the journal is by no means undirected or entirely open-ended. However, the assignment guidelines do not include specific models for students to imitate (not surprisingly, given that Rick wants to encourage students to write in ways that are personally meaningful and therefore welcomes a diversity of communicative forms) nor do they dictate a set of precise rules that define the composition of an appropriate journal entry.

L'exercice de compréhension de Lucien n'inclut pas de modèle spécifique comme tel. Les questions sont présentées avec un niveau progressif de complexité. Lucien suppose que les étudiants apprendront à développer leur pensée philosophique en faisant l'exercice et non en imitant un modèle dans le domaine ou en utilisant une série de règles. L'exercice en sociolinguistique reflète en partie ce principe; toutefois, il amène l'étudiant à observer comment les différents auteurs présentent leurs arguments. Je présente deux ou trois articles en classe où je démontre avec plusieurs explications comment les auteurs font connaître le contenu. En exploitant ces articles, je donne aux étudiants des directives très précises sur la façon dont ils devraient présenter leur projet. Nous étudions le contenu et la forme. Les tâches demandées dans ce travail amène l'étudiant à étudier comment les experts dans le domaine de la sociolinguistique s'y prennent pour qu'à leur tour il puisse 
présenter une analyse sociolinguistique.

Of the four activities, Dave's exercise explicates most concretely the features of academic genre that he expects his students to be able to identify and, to some extent, compose. His guidelines for writing a summary, for example, list specific features that the summary should include $(A p p e n d i x)$ ), as does his explanation of the abstract he wants his students to write. This kind of explicit description of features is intended to help students perform the exercise successfully. As Dave notes, "I take pains to demystify the task.... I provide very clear instructions on how to get good marks.... It is very important that they know how to satisfy my requirements. The marking scheme is designed to call their attention to the elements I want them to be aware of " (Appendix B). Dave's assignment description emphasizes the characteristics of successful final products, but it provides less guidance on the compositional processes for crafting these final products. Perhaps students' abilities to undertake this assignment successfully would be further enhanced if Dave offered as much guidance on writing processes as he does on the written products that he hopes students will create. In this way, the activity's design might be said to address "both the formal tyranny of standard structures and the heuristic processes through which generic form guides the creation and comprehension of substance" (Coe, p.182).

\section{Conclusion}

In sum, through the pedagogical writing to learn activities that our colleagues have designed, students potentially begin to become enculturated into disciplinary and professional genres of thinking and communicating. However, as we have seen, the ways in which this can occur vary considerably according to each teacher's disciplinary expectations and understanding of what it means to "write to learn". Further, while we have assumed that the study of the design of these pedagogical genres is valuable in its own right, obviously a fuller appreciation of the role that they play in the development of professional genre knowledge requires research into student practices and perceptions as well.

Nous interprétons les but de ces exercices comme pouvant développer chez l'étudiant des stratégies de compréhension, d'analyse et de synthèse qui encouragent l'écriture à favoriser une croissance intellectuelle. De plus, nous interprétons ces buts comme pouvant enseigner à l'étudiant à déceler comment un professionnel utilise les connaissances spécifiques aux formes et comment la connaissance cognitive est liée aux activités de la discipline afin que les étudiants (débutants) en écrivant apprennent les connaissances spécifiques aux formes de la discipline. 
Finally, in closing we wish to note that the learning which takes place through these activities is not only in the direction of novices learning from experts and about expert forms of knowledge making. In addition, experts - that is, the teachers who represent and work in the discipline - learn from their students' writing (see figure 6).

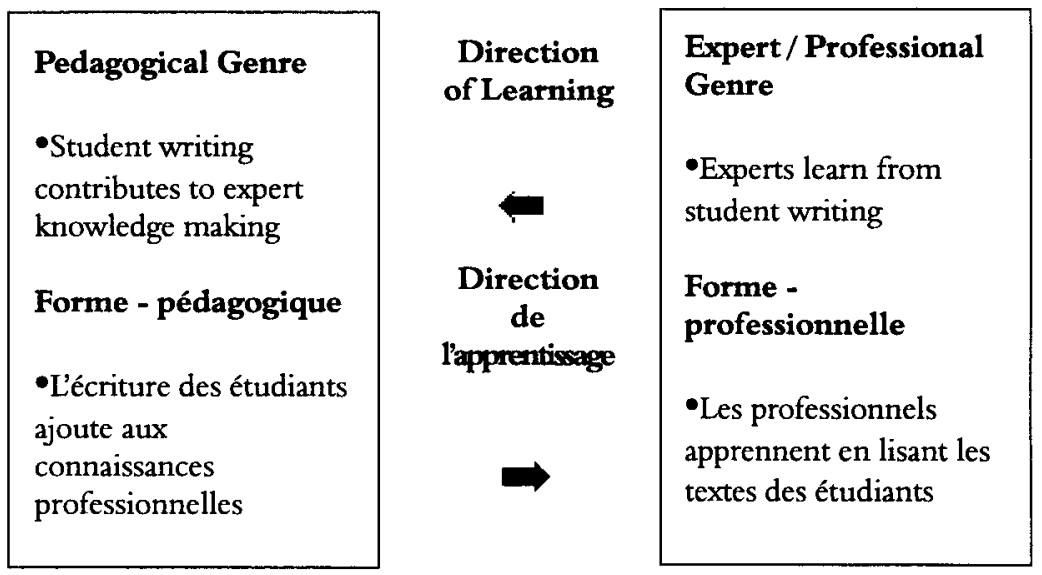

Figure 6

Rick Vanderlee, for example, hopes that students will share their learning journals with him so that he can "see myself through your eyes and...become aware of what I do that you find helpful and affirming and what I do that you find confusing or demeaning" (Appendix A). For Dave Robinson, the exercises that he asks his students to complete introduce him to numerous articles that he may well not have read yet; as he says, the exercises "contribute to my professional education and my stock of teaching materials" (Appendix B). Lucien Pelletier anticipe en lisant les réponses aux questions demandées qu'il pourra comprendre la pensée de ces étudiants face à la réalité du bonheur. En ce qui me concerne, c'est un peu la même situation que Dave Robinson; ces exercices me permettent 1) de lire certains articles qui ne font pas partie de ma bibliographie et qui contribuent à mon éducation professionnelle et 2) d'ajouter des ressources pédagogiques à mon enseignement. In the views of our colleagues, the pedagogical genres that they assign do not function uni-directionally to to ensure "successful student absorption into existing systems" of "disciplinary order" (Malinowitz, p.294); according to them, student writing contributes, at least to some extent, to their own expert knowledge-making. This suggests a dynamic and to some degree reciprocal relationship between pedagogical and professional genres. 


\section{Notes}

1. Susan Peck MacDonald uses the phrase "textual knowledge-making" in her book Professional Academic Writing.

2. Writing intensive courses at our university are regular courses from any discipline and at any level which foreground writing as an important part of the learning process. These courses are offered voluntarily by interested faculty.

3. We are extremely grateful to our colleagues Lucien Pelletier, Département de philosophie, University of Sudbury; David Robinson, Department of Economics, Laurentian University; and Rick Vanderlee, formerly School of Nursing, Laurentian University and now School of Nursing, University of Calgary for generously sharing their approaches to writing across the curriculum with us and for permitting us to use their writing to learn activities as the basis for this study. The fourth activity to be discussed, from Sociolinguistique, has been designed by Renée Corbeil.

4. We are grateful to Russ Hunt and others at the Inkshed 15 conference for pointing out this distinction between the cognitive and expressivist traditions to us.

5. This perspective owes much to the 1970 s research of scholars such as $L$. Flower and J. Hayes as well as C. Bereiter and M. Scardamilia, among others.

6. The term "expressivist" derives from Britton's discussion of "expressive writing" in Development of Writing Abilities (1975).

7. Citing the work of Ramanathan and Kaplan, Johns goes on to caution 
that "'voice' is an Amerocentric concept, which is highly problematic for students who are not mainstream North Americans because these students are not accustomed to speaking or writing in social contexts with 'personal voices"'(p.10).

\section{References}

Aylwin, Ulric. "Usage et maîtrise de la langue dans tous les cours." Pédagogie collégiale 2 (1989).

Berkentotter; Carol and Thomas Huckin. Genre Knowledge in Disciplinary Communication. Hillsdale, NJ: Lawrence Erlbaum, 1995.

Connolly, Paul. "Writing and the Ecology of Learning". Writing to Learn Mathematics and Science. Ed. Paul Connolly and Teresa Vilardi. New York, NY: Teachers College Press, 1989.

Coe, Richard M. " 'An Arousing and Fulfilment of Desires': The Rhetoric of Genre in the Process Era - and Beyond" in Freedman and Medway, Genre: $181-190$.

Freedman, Aviva. "Learning to Write Again: Discipline-Specific Writing at University." Carleton Papers in Applied Language Studies 4 (1987): 95-115.

Freedman, Aviva, and Peter Medway, eds. Genre and the New Rhetoric. London: Taylor and Francis, 1994.

- Learning and Teaching Genre. Portsmouth, NH: Heinemann, 1994.

Geisler, Cheryl. Academic Literacy and the Nature of Expertise. Hillsdale, NJ: Lawrence Elrbaum, 1994.

Johns, Ann M. Text, Role, and Context: Developing Academic Literacies. Cambridge, UK: Cambridge UP, 1997.

Jones, R. and J. Comprone. "Where Do We Go Next in Writing Across the Curriculum?" College Composition and Communication 44.1 (1993): 59-67.

Knoblauch, C. and L. Brannon. "Writing as Learning Through the Curriculum." College English 45.5 (1983): 465-475.

Lecavalier, J., et A. Brassard. L'enseignement stratégique en lecture et écriture. Collège de Valleyfield, 1992. 
MacDonald, Susan Peck. Professional Academic Writing in the Humanities and Social Sciences. Carbondale: Southern Illinois UP, 1994.

Malinowitz, Harriet. "A Feminist Critique of Writing in the Disciplines." Feminism and Composition Studies: In Other Words. Ed. Susan C. Jarratt and Lynn Worsham. New York, NY: Modern Language Association of America, 1998.

Miller, Carolyn. "Genre as Social Actio." Genre and the New Rhetoric. Ed. Aviva Freedman and Peter Medway. London: Taylor and Francis, 1994.

Paré, A. and G. Smart. "Observing Genres in Action: Towards a Research Methodology." Genre and the New Rhetoric. Ed. A. Freedman and P. Medway. London: Taylor \& Francis, 1994.

Reither, James. "Writing and Knowing: Toward Redefining the Writing Process." Landmark Essays on Writing Process. Ed. Sondra Perl. Davis, CA: Hermagoras Press, 1994.

Walvoord, Barbara, and A. Kimbrough Sherman. "Managerial Decision Making: Sherman's Business Course." Thinking and Writing in College: $A$ Naturalistic Study of Students in Four Disciplines. Barbara E. Walvoord and Lucille Parkinson McCarthy. Urbana, IL: NCTE, 1990. 


\title{
Appendix A: R. Vanderlee's Assignment Description
}

\section{Monthly Summary Reports}

\author{
Rick Vanderlee
}

\section{Writing Activities to Asses Learning}

Satisfactory completion of the course will be demonstrated by learners through completion and submission of weekly Critical Incident Questionnaire responses, a Learning Journal and completion of a Participant Learning Portfolio related to your learning in this course. The following sections will explain in more detail my ideas about the evaluation tools that will be used in this course.

\section{Critical Incident Questionnaire (CIQ)}

The CIQ is a single-page form that will be handed out at the end of class each week. It comprises five questions, each of which will ask you to write down some details about events that happened in the class, in lab or in practice that week. Its purpose is not to determine what you like or didn't like about the class or learning activity. Instead, it will get you to focus on specific, concrete happenings that were significant to you. At the end of the term, you will be expected, as part of your assigned course work, to hand in a summary of your responses. This summary will be part of the Participant Learning Portfolio that will be described later in this syllabus. The intent of completing weekly CIQs is to make the course a better learning experience for you. The CIQ will make the class more responsive to any concerns you may have individually and as a group by alerting us to any ambiguities or confusions you may have about what is happening in this course. It will also help you find out about yourself as a learner, and finally, it will help build up important material for the assessed Participant Learning Portfolio.

At what moment in the class this week did you feel most engaged with what was happening? 
At what moment in the class this week did you feel most distanced from what was happening?

What action that anyone (teacher or student) took in class this week did you find most affirming and helpful?

What action that anyone (teacher or student) took in class this week did you find most puzzling or confusing?

What about the class this week surprised you the most? (This could be something about your own reaction to what went on, or something that someone did, or anything else that occurs to you.)

\section{Learning Journal}

The purpose of this journal is three-fold. First, I hope it will give you some insight into your own emotional and cognitive rhythms as a learner and professional. Reflective journal writing is an opening, a way to explore what we can become without being judged. By this, I mean that you will become more aware of how you go about organizing your learning and knowing, what kinds of learning tasks you are drawn to, what tasks you resist and seek to avoid, what conditions encourage you to take risks in your learning, what warning signals indicate that you are hitting an emotional low, and what factors tend to keep you going through the "quitting times" of low morale, depression and loss of confidence. A deeper understanding enables us to integrate former learning with experience, to form relationships between parts of knowledge and to search for meaning. Second, I want you to learn to think critically not only about yourself and who you are but about the world you live in. Writing critically is an important skill of a professional that involves raising questions, explicating new thinking, and transforming your personal understanding of the world. Reflection will help you move to an action-oriented process of making changes and to think critically about issues causes us to reveal what we think about and take for granted related to the human condition; what decisions we make based on our perceptions; and, how justly, ethically and caringly we perform our actions. Third, and more selfishly, I hope that you will be ready to share some sections of your journal with me. That will help me to see myself through your eyes and to become aware of what I do that you find helpful and affirming and what I do that you find confusing or demeaning. Knowing these things will help me change how I behave toward you and toward future learners. It 
will also create better connections between the learning I feel is important and your own needs and concerns. I suggest that you keep your journal on a weekly basis, and that you try to make a date with yourself at the same time each week to spend about twenty minutes doing this. You should write about whatever seems important to you as you reflect on your experiences as a learner. If you'd like some structure to help you with the first few weeks' entries, try writing a few lines in response to the following questions, in addition to following any instructions specified in the learning activities:

What have I learned this week about myself as a learner?

What have I learned this week about my emotional responses to learning?

What were the highest emotional moments in my learning activities this week?

What were the lowest emotional moments in my learning activities this week?

What learning tasks did I respond to most easily this week?

What learning tasks gave me the greatest difficulties this week?

What was the most significant thing that happened to me as a learner this week?

What learning activity or part of a learning activity, or emotional response, most took me by surprise this week?

Of everything I did this week in my learning, what would I do differently if I had to do it again?

What do I feel proudest about regarding my learning activities this week?

What do I feel most dissatisfied with regarding my learning activities this week?

Don't worry if your answers to these questions overlap or if you feel one question has already been answered in your response to an earlier question. Do try and write something thoughtful and meaningful, however brief, in response to each question. Even noting that nothing surprised you or that there were no high 
or low emotional moments in your learning tells you something about yourself as a learner and the conditions under which you learn.

I will ask you for Monthly Analysis Reports to be submitted to me. In these monthly reports, I would like a cumulative analysis of the major themes, qualities, responses and characteristics that have emerged from your weekly entries. Use the same headings that you use for your weekly entries, or headings that we develop in class and add anything that seems important to say that has not already appeared in analysis. 


\title{
Appendix B: David Robinson's Assignment Description
}

\section{Training first and second year students to use an academic literature}

\author{
A Strategy and a Sample Assignment \\ David Robinson \\ Department of Economics Laurentian University
}

\section{Overview}

University graduates should be able to retrieve information from the academic literature. They should be able to follow a debate through the literature, summarize it clearly and provide adequate references.

To ensure that they can use the literature in at least one field by the time they graduate, we have to begin teaching them the basic skills and concepts from the first year we have them.

For several years I have been using a simple sequence of exercises designed to introduce students to the literature in economics. The exercises work well. They are popular with students, although not easy. They are easy to mark, and actually contribute to my professional education and my stock of teaching materials.

The concepts that the students must acquire quickly include

1. The concept of a journal

2. The elements of a journal article, including
a. Abstract
b. Acknowledgements
c. Defined problem
d. Conclusions
e. Applications
f. References
g. Notes

3. The concept of a citation 


\section{Basic tools they must acquire in any discipline include}

1. The set of journals in their field

2. A citation index or substitute for one

\section{The assignment sequence}

1. I have students summarize articles in one or more journals. I usually start by assigning each student one issue of the Canadian Journal of Economics. (The example I have reproduced offers a selection of journals.)

2. I usually ask for an abstract on the second assignment (as in the example).

3. I require them to find two articles that cite the one they discuss in the third assignment. I introduce the assignment with a careful and colourful introduction to the concept of citations and the use of a citation index. It is a major achievement to reach this point. Once they grasp this idea they have begun to understand a scientific or academic literature. Until they grasp this concept they have nor really been introduced to any discipline.

\section{On framing the assignments}

I take pains to demystify the task. I tell the class several times that I do not expect them to understand the whole article. I say I sometimes take a month or more to really understand an article. I emphasize that a skillful reader can "fake it", using the introduction, abstract, headings and conclusion to get a good idea about the content and often skipping the difficult parts. I also emphasize that writing effective summaries is a skill they will use in more advanced courses.

I provide very clear instructions on how to get good marks (see the example). I always mark generously. It is very important that they feel they know how to satisfy my requirements. The marking scheme is designed to call their attention to the elements I want them to be aware of.

\section{Strategic Thinking: Game Theory for Business and Social Science (Economics 2065)}

\section{Assignment 4}

\section{Purposes}

1. to make you read at least two journal articles

2. to introduce you to the Canadian Journal of Economics

3. to make you use the Social Science and Humanities Citation Index 
4. to make you write a formal abstract.

5. to make you summarize a discussion in the economics literature

\section{You are to}

(1)Find a game theory article in an academic journal and write about an eighthundred and ten word, typed, summary of that paper. The summary should make clear what the problem is that the paper addresses ( 5 per cent), why it matters ( 5 per cent), what data is used, what methodology is used (5 per cent) and what conclusions are presented ( 5 per cent). If there are qualifications, the summary should mention them. It should also include your own assessment (5 per cent) of the paper and its conclusions. If it is helpful in explaining the paper, you may include, with proper accreditation, diagrams or tables based on the material presented in the text. They do not count as part of the three pages required.

(2)Provide a list of other works (references, generally journal articles) to which you refer. The list must have at least three entries. They must be in the format used in the CJE (10 per cent).

(3)Write an appropriately graceful acknowledgment note as a footnote to the first page ( 10 per cent). If you have been unable to find anyone to talk to about the article, then acknowledge some imaginary friends. There are some nice examples of acknowledgments in the CJE, including some that are rather whimsical.

(4)Write an abstract of YOUR OWN PAPER (25 per cent). An abstract is separate from the paper. (Look the word up.) The form of an abstract can be seen in the CJE. An abstract is there to tell a reader if the article is of interest to her. It, like your summary, should state the problem the paper was written to address, or whatever else the paper sets out to do. It should say why the problem matters, it should describe the methodology, the data and the conclusions. The abstract is to be typed and on a separate sheet of paper. Remember that it is to be an abstract of your paper. Your paper itself could be seen as an extended abstract.

The 30 per cent unassigned marks for this assignment are automatic for completion of the project on time. Try to select an article that is related to your interests so you can use it in your term project.

\section{Some Journals We Have That Publish Game Theoretic Articles}

American Economic Review

American Journal of Political

American Journal of Sociology

Behavioural Science

British Journal of Political Science
Human Nature

Science International Studies Quarterly

Journal of Conflict Resolution

Journal of Biological Education.

Journal of Economic Perspectives 
Canadian Public Policy

Canadian Journal of Political Science

Comparative Political Studies

Environmental Ethics futures

European Economic Review

Games and Economic Behaviour
Journal of Personality and Social Psych.

Journal of Politics

Journal of Peace Research

Science

Simulation and Games

Social Psychology Quarterly Theory

and Society

You may find it useful to look in the items on reserve for this course to find references to articles that may interest you. Your text also refers to some articles of interest. 


\section{Appendice C: Description de l'activité de Lucien Pelletier}

\section{UNIVERSITÉ DE SUDBURY}

\section{DÉPARTEMENT DE PHILOSOPHIE}

1997-1998

PHIL 1105 FA

Introduction à la philosophie

Deuxième travail

Exercice de compréhension

Pendant de nombreuses années, le philosophe français Alain (1868 -1951) a publié à tous les jours dans la Dépêche de Rouen une brève réflexion philosophique, qu'il appelait un "propos". Voici le propos du 6 novembre 1922:

\section{Bonheur est Vertu}

Il y a un genre de bonheur qui ne tient pas plus à nous qu'un manteau. Ainsi le bonheur d'hériter ou de gagner à la loterie; aussi la gloire, car elle dépend de rencontres. Mais le bonheur qui dépend de nos puissances propres est au contraire incorporé; nous en sommes encore mieux teints que n'est de pourpre la laine ; “Je porte toute ma fortune avec moi". Ainsi Wagner portait sa musique et MichelAnge toutes les sublimes figures qu'il pouvait tracer. Le boxeur aussi a ses poings et ses jambes et tout le fruit de ses travaux autrement que l'on a une couronne ou de l'argent. Toutefois il y a plusieurs manières d'avoir de l'argent, et celui qui sait faire de l'argent, comme on dit, est encore riche de lui-même dans le moment qu'il a tout perdu.

Les sages d'autrefois cherchaient le bonheur ; non pas le bonheur du voisin, mais leur bonheur propre. Les sages aujourd'hui s'accordent à enseigner que le bonheur propre n'est pas une noble chose à chercher, les uns s'exerçant à dire que la vertu méprise le bonheur, et cela n'est pas difficile à dire; les autres enseignant que le commun bonheur est la vrai source du bonheur propre, ce qui est sans soute l'opinion la plus creuse de toutes, car il n'y a point d'occupation plus vaine que de verser du bonheur dans les gens autour comme dans des outres percées; $j$ 'ai observé que ceux qui s'ennuient d'eux-mêmes, on ne peut point les amuser; et au contraire, à ceux qui ne mendient point, c'est à ceux-là que l'on peut quelque 
chose, par exemple la musique à celui quis'est fait musicien. Bref il ne sert point de semer dans le sable; et je crois avoir compris, en y pensant assez, la célèbre parabole du semeur, qui juge incapables de recevoir ceux qui manquent de tout. Qui est puissant et heureux par soi sera donc heureux et puissant par les autres encore plus. Oui, les heureux feront un beau commerce et un bel échange; mais encore faut-il qu'ils aient en eux du bonheur, pour le donner. Et l'homme résolu doit regarder une bonne fois de ce côté-là qui le détourne d'une certaine manière d'aimer qui ne sert point.

M'est avis, donc, que le bonheur intime et propre n'est point contraire à la vertu, mais plutôt est par lui-même vertu, comme ce beau mot de vertu nous en avertit, qui veut dire puissance. Car le plus heureux au sens plein est bien clairement celui qui jettera le mieux par-dessus bord l'autre bonheur, comme on jette un vêtement. Mais sa vraie richesses il ne la jette point, il ne le peut; non pas même le fantassin qui attaque ou l'aviateur qui tombe; leur intime bonheur est aussi bien chevillé à eux-mêmes que leur propre vie; ils combattent de leur bonheur comme d'une arme; ce qui a fait dire qu'il y a du bonheur dans le héros tombant. Mais il faut user ici de cette forme redressante qui appartient en propre à Spinoza et dire: ce n'est point parce qu'ils mouraient pour la patrie qu'ils étaient heureux, mais au contraire, c'est parce qu'ils étaient heureux qu'ils avaient la force de mourir. Qu'ainsi soient tressées les couronnes de novembre.

Ce texte est admirablement écrit, mais pour le comprendre il faut en faire une lecture attentive. Lisez-le donc en vous efforçant de comprendre chaque phrase ou membre de phrase. Recherchez dans un dictionnaire le sens des mots que vous ne comprenez pas.

Puis, répondez par écrit aux questions suivantes:

a)Dans le premier paragraphe, Alain distingue deux types de bonheur. Quels sont-ils?

b)Dans le deuxième paragraphe, Alain distingue l'opinion des sages anciens et celle des sages d'aujourd'hui quant au bonheur. Il précise que les sages d'aujourd'hui ont deux conceptions différentes du bonheur. Quelles sont donc toutes ces opinions, anciennes aussi bien que modernes? Auquel des deux types de bonheur distingués au paragraphe précédent chacune de ces conceptions correspond-elle?

c) Toujours dans le deuxième paragraphe, l'auteur réfute l'une des deux conceptions modernes quant au bonheur: dites laquelle. Par quel argument 
est-elle réfutée ? Lorsqu'Alain dit par exemple qu'on ne peut donner la musique qu'au musicien, ou qu'il ne sert à rien de semer dans le sable, que veut-il dire?

d)Dans le troisième paragraphe, Alain réfute la première conception moderne du bonheur. Quel est son argument ? En outre, lorsqu'il écrit : "le plus heureux au sens plein est bien clairement celui qui jettera le mieux par-dessus bord l'autre bonheur", quel est cet "autre bonheur" auquel il fait allusion?

e)Expliquez le sens du titre.

f)Quelqu'un vous dit que chacun a le devoir d'obéir aux règles de la morale même si ça lui déplaît et qu'en cela seul consiste la vertu. Que répondrait Alain?

g)Quelqu'un vous dit que la seule règle qui compte, c'est d'acquérir le plus de biens possibles afin d'être heureux. Que répondrait Alain ?

h)En conclusion, cette lecture vous a-t-elle appris quelque chose ?

Longueur de la réponse demandée: environ 7 pages.

Valeur: $15 \%$ de la note finale.

Il est recommandé aux personnes inscrites au programme LIP de faire réviser leur travail au Centre de rédaction universitaire avant de me le remettre.

Date de remise: le 2 décembre 1997 


\section{Appendice D: Description de l'activité de Renée Corbeil}

\section{Cours de sociolinguistique}

\section{Renée Corbeil}

Le travail pour ce cours consiste à choisir un pays ou le français est parlé, soit comme langue majoritaire, soit comme langue minoritaire et à faire une analyse sociolinguistique. L'étudiant doit discuter de l'historique, du statut politique, de la situation socio-économique et du contexte culturel du pays choisi.

Exposé oral:

L'étudiant doit présenter son travail de recherche en classe. Afin d'accomplir cette tâche, il discute de sa recherche, avec moi, deux ou trois fois avant la date de l'exposé. La première fois, il présente sa bibliographie et propose son plan. À la deuxième rencontre, il soumet son plan révisé, son modèle de présentation et un article qu'il distribuera aux étudiants une semaine avant la classe. Cet article doit être accompagné de questions de compréhension que nous développons ensemble. Il doit tenir un journal de toutes ses démarches et ses commentaires qu'il remettra avec son travail. Toutes ces directives lui sont remises par écrit et sont expliquées en classe.

L'activité "écrire pour apprendre" que j'ai choisi de présenter est un exercice pour encourager l'étudiant à écrire sur le contenu du cours après chaque classe.

Pendant l'exposé oral, les étudiants prennent des notes. Ils doivent organiser et préparer leurs notes après chaque classe afin de les présenter oralement à la prochaine période. Un temps de 30 minutes est alloué pour cette courte présentation et pour la discussion qui suit. La courte présentation doit avoir un résumé de la présentation magistrale, des faits intéressants et deux questions auxquelles les étudiants de la classe répondront. L'étudiant responsable de la présentation magistrale apporte des précisions s'il y a lieu. Certaines de ces questions sont choisies pour l'examen final. L'étudiant qui fait le résumé de la présentation est choisi au hasard (de cette façon, je m'assure que le travail est fait par tous les étudiants à chaque classe). Cet exercice vaut $15 \%$.

Après avoir utilisé ce genre de pédagogie, je m'aperçois que les étudiants prennent leurs notes en fonction de leurs besoins et ils sont plus attentifs en classe. Les questions qu'ils posent à l'étudiant, ne se limitent pas à des petits détails (date, population...), mais se concentrent plus sur l'analyse qu'un sociolinguiste peut faire (l'avenir de la langue dans ce pays, comparaison avec son propre pays etc.). Le but de cet exercice est de les faire écrire pour pouvoir discuter de leurs connaissances avec d'autres étudiants et non de les faire apprendre par coeur des faits seulement pour réussir à l'examen. Je crois que cette pratique encourage la pensée et non la mémorisation. 